\title{
Optimization of work and rest hours for navigation officers on the ship
}

\author{
H. Simkuva ${ }^{1}$, A. Purins ${ }^{1}$, S. Mihailova ${ }^{2}$, and I.J. Mihailovs ${ }^{2}$ \\ ${ }^{1}$ Latvian Maritime Academy, Riga, Latvia \\ ${ }^{2}$ Rīga Stradiņš University, Riga, Latvia
}

\begin{abstract}
The topic of the research as a whole is dedicated to studies of the work load of navigation officers and, consequently, is related to the current international research on the quality of working life. Issues of seafarers' working time are very topical because in recent years the load of navigation officers has significantly increased, either due to increase in shipping intensity, or in the context of the new international maritime law, for example, compliance with the requirements of the ISM CODE (International Management safety Code), THE ISPS (The International Ship and Port Facility Security Code). Irregularities are observed in practice of the seafarers' working hours and rest hours, and even the mismatch, as presented in the port of inspection materials. This article is intended to assess the 2nd and 3rd Officer's load compliance with the regulatory enactments for the work and rest regime to develop proposals to load optimization. Load analysis of Navigation officers is based on international maritime regulations that determine the work and rest regime on ships STCW (The International Convention on Standards of Training, Certification and Watchkeeping for Seafarers), MLC (Maritime Labour Convention). In the article, concrete data is used from the research, which was conducted 18 months on the Handy type of tanker from July, 2012 till December, 2013 in the real time mode. In the article is also concrete data used from 340 survey respondents, which reflects the views of the navigation officers on violations of the work and rest regime on the ship and the fatigue issue.
\end{abstract}

Key words: watchkeeping regime, fatigue, congestion, the rest time, navigation incident, navigation crashes, watchkeeper, timekeeper, Maritime Single Windows 2 / O (2nd Officer), 3 / o (3rd Officer), SMS (Safety Management System).

\section{Introduction}

Over the last 20 years, shipping intensity in the world has increased more than 4 times, and with it the workload of the ship's crew has grown significantly, that is proved by the Port inspection materials, and the documents for seafarers' watches (American Geophysical Union (AGU, 2014). At the same time, the work and rest regime breaches, and discrepancies are regularly fixed on ships. There are various causes of the increase in the load: 1) still there is a tendency to reduce the number of the crew on board (Smith, 2007), 2) shipping intensity has increased (AGU, 2014); 3) new regulations, such as ISM Code and ISPS CODE requirements, have been introduced. In particular, the increase relates to the navigation officers, especially 2nd and 3rd officers, due to frequent port rotation, complex maritime areas, mooring operations, cargo operations, and administrative work leads to systematic violations of minimum hours of rest and regular overload. Of particular importance is the 
increase in the load of seafarers by ship owners' economic interest to reduce the composition of the crew, which, in turn, substantially lowers maritime safety due to officers' fatigue. This is especially relevant for ships carrying dangerous goods such as chemical tankers, because in an emergency, the consequences are disastrous. Studies show that human error factor is to blame for accidents of $84 \%-88 \%$ on tankers, and up to $96 \%$ in cases of collisions (Marine and Coastguard Agency, 2010). Up to now research on seafarers' work (Horizon.Research report: A wake-up call, 2012) reveals that seafarers' congestion on shipboards is also associated with shortcomings in organization of seafarers' work on the ship and precise records of work load and working time on the ship. In this article, 2nd and 3rd officers' work load will be assessed, as well as organization's capacity on board of the Handy type of tanker within 18-month period from 2012, July till 2013, December with particular watches $6 / 6,4 / 8,48 /-8 / 4$, as the load of these officers is one of the busiest on vessels (Puriņš, Šimkuva, 2015). Without direct navigation obligations on the watches, the officers' responsibilities include SMS functions, the port inspection procedures, ship's passage plan development, the administrative work, ships berthing operations. They are in addition to the obligations to regular officers' guard duties, for which separate time is not provided and thus it requires more work from the officer, which is not compensated by adequate time for rest and sleep.

\section{The methodology and methods used in the research}

The research is based on the provisions of the STCW 2010 ((The International Convention on Standards of Training, Certification and Watchkeeping for Seafarers) and MLC (Maritime Labour Convention) Convention methodology to study navigation officers' working and rest hours.

The study was conducted, using the following scientific methods - analytical, comparative, sociological survey and observation. Study of the navigation officers' working and rest hours performing watchkeeping duties on the board was carried out in the period of 18 months. For processing of the data ISF Watchkeeper 3 application was used, which is an internationally recognised accounting program and the working time of seafarers on board ships is widely used. During the study, a survey which involved 340 the navigation officers was carried out on work and rest periods, fatigue factor and on options to optimize the navigation officer's capacity (Puriņš, 2015). The data obtained was treated with a specialised statistical programme IBM SPSS and Kendel Tau rank correlation coefficient.

Seafarers' hours of work load and the legal regulation of EC Directive 2003/88/EC on the Working time, STCW (2010) and MLC (2006) convention requirements.

The current law in the organization of work of seafarers is the European Commission Directive on working time, adopted in 2003 (Directive 2003/88/EC), which deals with the organisation of working time and sets standards for the protection of health and safety of workers. For purposes of this Directive, with regard to the employment of seafarers it is asked to quantify the daily rest, breaks, weekly rest, night work hours. In particular, the Directive highlights the right to "adequate rest", which is a very important issue for seafarers. Seafarers employed aboard the ship without regulatory watchkeeping duties, occasionally have to take individual responsibilities on board the ship, which are not intended to be precise, and the time required for their execution is not strictly limited. Often there are problems with organisation of working time, therefore the ILO Convention No. 180 concerning Seafarers Hours of Work and the Manning of Ships (ILO Convention No 180, Geneva, 22 October 1996) is violated. In order to monitor and control the work of seafarers on 26 January, 1982 the Paris Memorandum of Understanding was signed, which regulates the procedures 
Table 1. Working and rest time regulation in shipping (according to the STCW 2010 and MLC 2006).

\begin{tabular}{|l|l|l|l|l|}
\hline Convention & $\begin{array}{l}\text { Work / rest } \\
\text { in any 24 hour } \\
\text { period }\end{array}$ & $\begin{array}{l}\text { Work / Rest } \\
\text { in 7 days }\end{array}$ & $\begin{array}{l}\text { Rest period amount } \\
\text { and duration }\end{array}$ & $\begin{array}{l}\text { Notes and } \\
\text { exceptions }\end{array}$ \\
\hline MLC 2006 & $\begin{array}{l}\text { A maximum } \\
\text { 14 h of work } \\
\text { A minimum } 10 \mathrm{~h} \\
\text { of rest }\end{array}$ & $\begin{array}{l}\text { A maximum } \\
72 \mathrm{~h} \text { of work } \\
\text { A minimum } 77 \mathrm{~h} \\
\text { of rest }\end{array}$ & $\begin{array}{l}\text { Not more than 2 rest } \\
\text { periods, one of which } \\
\text { shall be at least } 6 \mathrm{~h} . \\
\text { The interval between } \\
\text { rest periods of less than } 14 \mathrm{~h}\end{array}$ & $\begin{array}{l}\text { The records Shall } \\
\text { be made each day. } \\
\text { Exceptions are } \\
\text { allowed, by means } \\
\text { of Collective } \\
\text { Agreements. }\end{array}$ \\
\hline $\begin{array}{l}\text { STCW 2010 } \\
\text { (Manila annex) }\end{array}$ & $\begin{array}{l}\text { A minimum } \\
10 \mathrm{~h} \text { of rest }\end{array}$ & $\begin{array}{l}\text { A minimum } \\
77 \mathrm{~h} \text { of rest }\end{array}$ & $\begin{array}{l}\text { Not more than 2 rest } \\
\text { 2 rest periods, one of } \\
\text { The interval between rest } \\
\text { periods of less than } 14 \mathrm{~h}\end{array}$ & $\begin{array}{l}\text { The records Shall } \\
\text { be made each day. } \\
\text { Exceptions are } \\
\text { allowed. }\end{array}$ \\
\hline
\end{tabular}

for port State control. It has also competence in respect of seafarers' hours of work and rest period check on the ship. In order to improve the organisation of working time of seafarers, to prevent irregularities and inconsistencies in the work and rest regime on board, The ILO adopted in 2006 MLC (Maritime Labour Convention (2006)), which lays down the requirements for the seafarers' work on a ship. In Latvia it entered into force on 1 August, 2013. The International Convention on Standards of Training, Certification and Watchkeeping for Seafarers the Convention in 2010 defines the requirements of the Manila amendments with regard to organisation of work, and the requirements for working and rest time rationing (STCW Manila amendments 2010).

Working and rest time regulation in shipping according to the STCW 2010 and MLC 2006 is shown in Table 1.

Table 1 shows that:

1) The maximum working time should not exceed:

a) 14 hours in 24-hour period, and

b) 72 hours in seven-day period.

2) The minimum rest period should not be less than:

a) 10 hours in 24-hour period, and

b) 77 hours in a seven-day period (Maritime Labour Convention (2006) Chapter 2, Sect. 2.3.). But in the STCW Convention only the minimum rest period is mentioned,

c) 10 hours in 24-hour period, and

d) 77 hours in seven-day period (STCW Manila amendments (2010) Code, Part A, Chapter VIII-Watchkeeping).

According to MLC Convention a seafarer is allowed to work up to 91 hours per week, but in the STCW Convention of 2010, exceptions can reach work even up to 98 hours per week. Compared with the other sectors of transport, maritime transport sector workers belong to the most loaded transport sector, which allows working 13 hours a day, every day, for months in a row. The number of work hours per week during the long voyage leads to congestion and fatigue, therefore the STCW and MLC working hours are to be regarded as the maximum limit rather than the recommended. 


\section{Research object and research procedure}

During the assessment of 2nd and 3rd Navigation officers' work on board, which is being held 6/6, 4/8 / / -8, 4/8 / 4 watches, using Watchkeeper3 system which records watch hours, working hours and work fixed in logbooks, and analysing the survey materials, it is concluded that the mode of $6 / 6$ on Handy type tanker causes most of work and rest regime violations, although this watch mode is used widely enough. The examination of the 18-month period revealed that the second and third officers' standing watch in 4/8 with $6 / 640 \%$ of cases have worked in $6 / 6$ mode (see Image 1) which is attributable to the regular port rotations, with short voyages and frequent tank cleaning operations. In addition, neither the MLC nor STCW Convention, determining the seafarers' hours of work and hours of rest, shall not be included in the working time 'SIRE Ship Inspection Report Programme, which is necessary to meet the requirements of the inspections of all kinds of tankers. 'SIRE shall require that watch officer must carry out the security inspection during the dark hours of the day. This inspection shall include in particular the examination of superstructure, enclosed spaces, which are not fitted with smoke, fire, or heat sensors. In practice, this inspection takes 15-20 minutes. Such procedure automatically does not respect the minimum rest periods as required by the Conventions. It is not possible to use an uninterrupted rest period of 6 hours. In all procedures, especially in port, officers have only about 4-4.5 hours of sleep. Also, 2nd and 3rd officers at ports are responsible for the preparation of the voyage, its correction, the ship's preparation for certain inspections checks, SMS functions and administrative work.

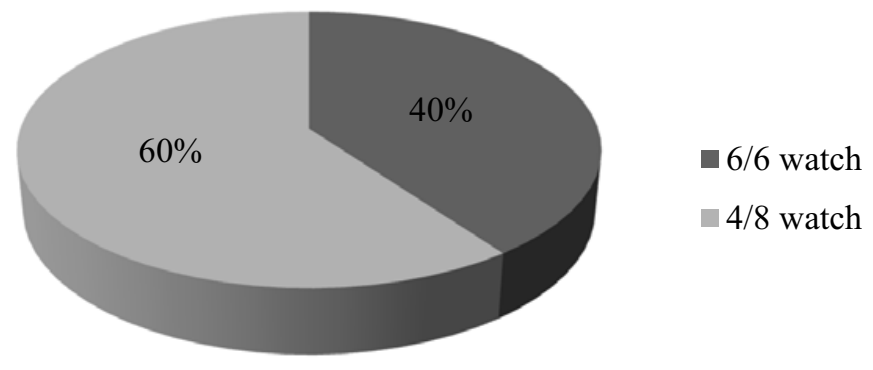

Figure 1. 3rd and 2nd Officers' watches during 18-month period (Puriņš, Šimkuva, 2015).

The survey included the question whether the watch mode $6 / 6$ gives the possibility to have a sufficient rest (Fig. 2). 56\% of respondents acknowledged that the regime in $6 / 6$ does not provide sufficient rest and recommended to prohibit the use of such watch arrangements, making appropriate amendments to the STCW and MLC Conventions.

\section{Question1: Does the watch mode 6/6 provide sufficient time to relax?}

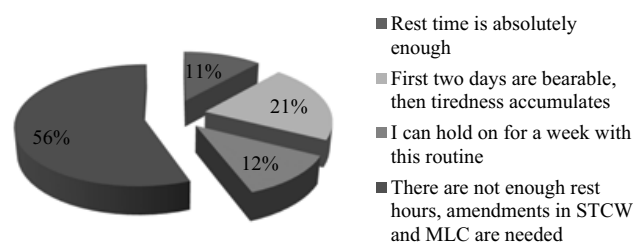

Figure 2. Results of answers to Question 1 (Purinš̌, 2015). 
The 4/8 and 4/8 -8/ 4 watchkeeping regime does not exclude violations, as it is shown in the Fig. 3. The results show that the most common violation is the "Less than 10 hours in 24 hour rest period" and "continuous rest less than 6 hours", which is a serious breach and does not ensure sufficient rest. The situation with the rest period violations is particularly dangerous if rest period violations are regular. In the survey the question was asked and answer results are shown in Question 2 and Fig. 4.

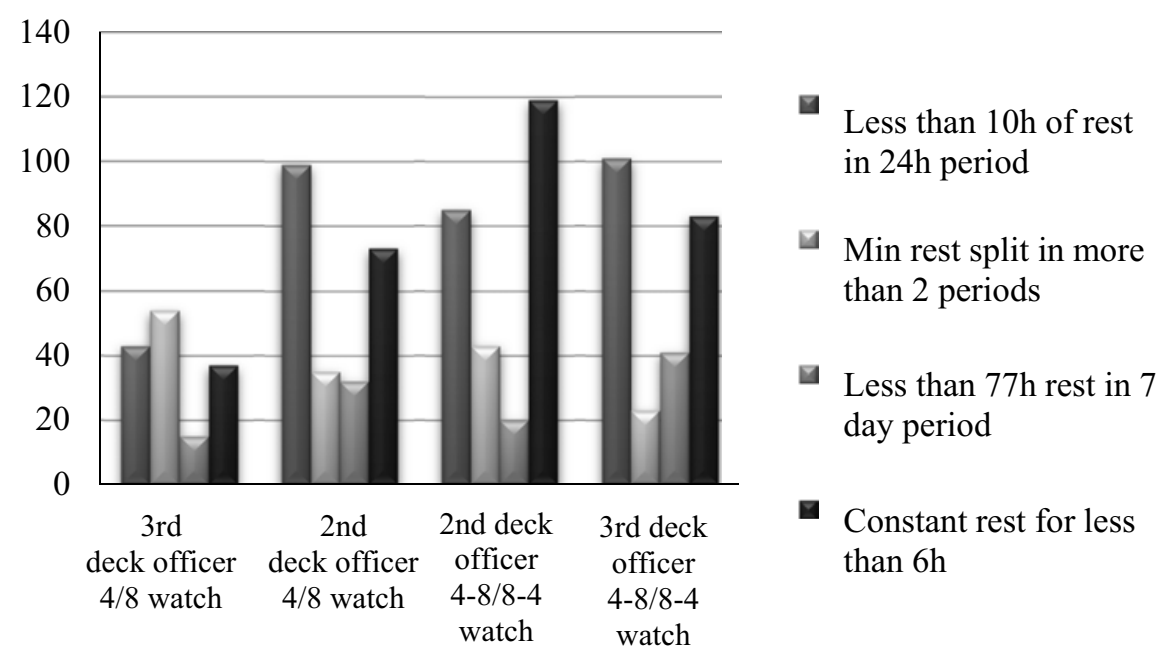

Figure 3. Number of offences by classification (Marine and Coastguard Agency, 2010; IMO Resolution A.890 (21); Puriņš, 2015).

Results of Question 2 and Fig. 4: How many days of the month, discrepancies appear with the STCW Convention and the MLC concerning the working time and rest time?

Only $1 \%$ of respondents say that they do not face the work and rest period violations during the month (Fig.5), 34\% answer that such type of infringement is regular, but $9 \%$ systematically fails to comply with the minimum rest hours. Thus, overall, $44 \%$ of respondents admitted that rest period violations are regular and systematic.

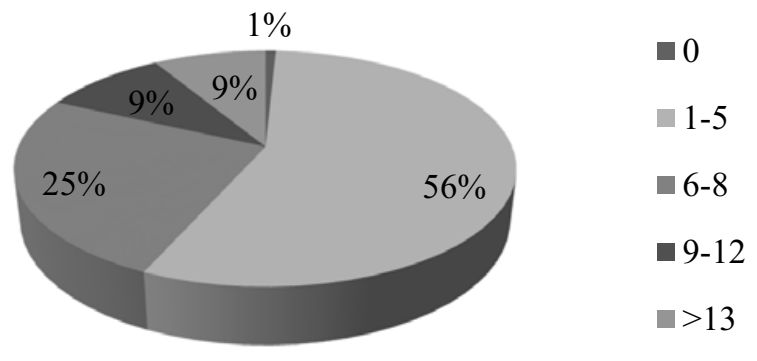

Figure 4. Results of answers to Question 2 (Purinš̌, 2015).

Figure 5 shows that the working period of 18 months for the second and third officers, on average 15 days within the month, is the minimum rest period infringements (both for the second and third officers), which is above the permissible rules following the company's SMS (1 violation a week, or 4 violations during the month). 
Taking into account the obtained results, during the research the officers' load was tested under the condition that the company increases crew size and includes the $4^{\text {th }}$ member (Deck Officer) in the crew. If an additional watch officer is employed, it would be possible to divide the work and rest hours and the number of infringements would be reduced by $99.6 \%$. Only 1 violation appeared during the 18 months, which in Fig. 5 is shown with a yellow curve in the $4 / 8$ watch.

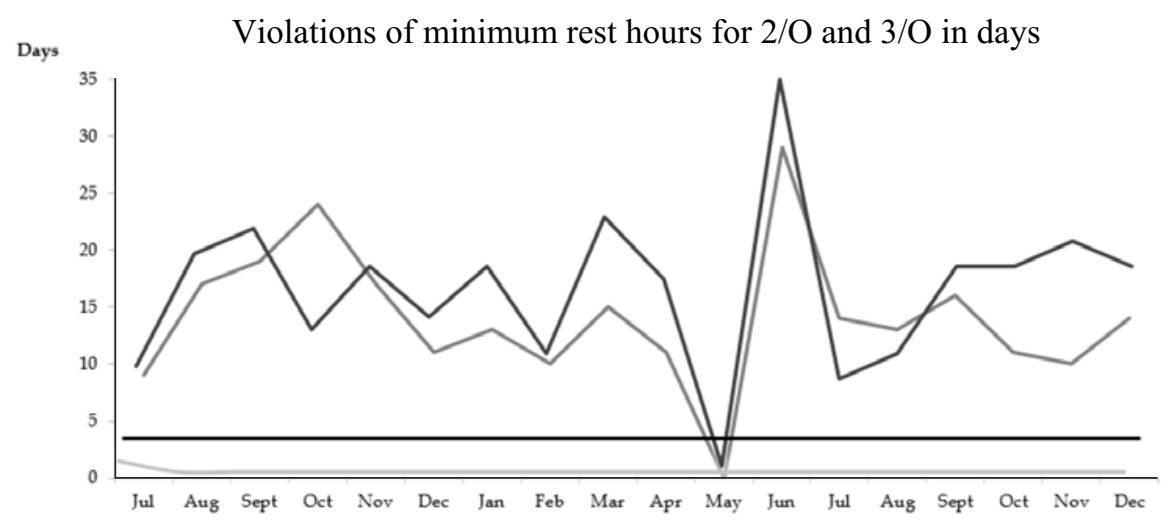

Accepted norm

Unfixed watch $4 / 8$ with $6 / 6$

Unfixed watch $4 / 8$ with $4 / 8-8 / 4$

Only $4 / 8$ watch

Figure 5. Violations of the minimum rest hours for both 2nd and 3rd officers (Purinšs, 2015).

Recognising the fact that the work and rest regimen is violated, the officers were forced to hide the situation to exit port inspections. Most of it was done by adjusting fixed working hours in the Watchkeeper3 system. This fact is also confirmed by the results of the surveys (see Question 3 and Fig. 6).

Question 3: Have you ever forged your work / rest period records?

$52 \%$ of the respondents distort their work and rest period records (Fig. 6). Almost one third (29\%) admits that the captain is a person who makes to falsify the working and rest time, in order to avoid discrepancies in relation to the STCW Convention. 23\% distorts their records before the inspection. Only $31 \%$ say that never breach the work and rest period regime, all overtime is written down.

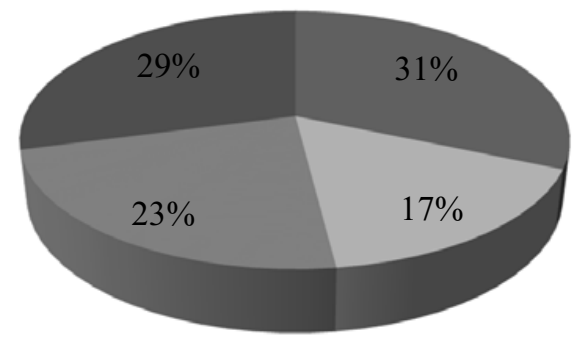

I always record all overtime: during watches on the bridge and in ports

I never record overtime spent on the bridge

I sometimes falsify it before the inspection

- Master makes us falsify the records, so there are no violations of STCW

Figure 6. Results of answers to Question 3 (Puriņš, 2015). 


\section{Conclusion}

1) In maritime sector, the work regime of navigation officers is one of the most overloaded. According to MLC, in one week it is permitted to have 91 work hours, but according to the STCW Convention even 98 hours of work. Analysis of this regime within 18 months is based on ship load and on 2nd and 3rd Officers load, and it was found that the work and rest regime specified in the Conventions is violated due to multiple causes. The main reason for these offences are insufficient number of crew members, due to the increased number of officers in the load, as well as weaknesses in the records of the seafarers' working time and work load planning. Records of work hours on board by Watchkeeper system allow adjustment of working hours.

2) In addition to crew with the 4.officer, will be optimized the 2 nd and $3^{\text {rd }}$ officer's load, but the work and rest period violations can be reduced by $99.6 \%$. With the 4.officer introduction the research results were examined in the BSM company and on Latvian shipping ships (Puriňš, Šimkuva, 2015), on its ships, practically succeeded in reducing the work and rest period violations. Thus, in assessing the work and rest period violations, the proposal is to introduce mandatory 4th navigator for "Handy" type of tanker vessels carrying dangerous cargo.

3 ) The $4^{\text {th }}$ officer is not only the most efficient means of fighting with the work and rest period violations, but also an effective solution to combat such accident types as a ship collision and grounding, because, as research shows $82 \%$ of cases such disasters and errors happening due to officers fatigue. Fatigue may have different origins, but regular working hours are the main cause of the overload (SHE Manual, 2011).

4) Conventions and the commonly used $6 / 6$ watchkeeping regime, allowed to vessels, leads to regular minimum hours of rest violations. Such regime, financially advantageous for shipping companies, is one of the main causes, which forces the seamen to falsify data on actual work and the rest of the ship to prevent problems with port inspections. This conclusion is confirmed by both the survey and study materials on board during the 18-month period, analysis of the records of the documents. Insufficiently secure "Watchkeeper 3" working time accounting system on board promotes and allows falsification. Thus, the proposal is to limit the use of the $6 / 6$ watch and clarify the conventions because the work adversely affects people's capacity for work. As research shows, the maximum continuous sleep duration, working in 6/6 mode is only 4.5 hours, which is unsatisfactory and leads to excessive fatigue. (Smith, A., Allen, P., 2006).

5) The only acceptable watch mode is $4 / 8$, which allows complete rest, not leading vessels to additional risks and violating the working and rest time, in addition to that, there is a need for an effective planning of working time for which the leading ship's crew is responsible.

\section{References}

[1] American Geophysical Union (AGU), (2014). Worldwide ship traffic up 300 percent since 1992 https: //news . agu . org/worldwide-ship-traffic-up-300percent-since-1992; Maritime News, November 18,2014/ http://www . marinelink. com/news/worldwide-traffic-since381037.aspx

[2] Directive 2003/88/EC of the European Parliament and of the Council of 4 November 2003 concerning certain aspects of the organisation of working time / Official Journal L 299, 18/11/2003 P. 0009-0019.

[3] Horizon Research report: A wake up call (2012), 1-32 p. http://www. warsashacademy.co.uk/about/resources/final-horizon-report-finalas-printed.pdf 
[4] ILO Convention No. 180, Geneva, 22 October 1996, concerning Seafarers' Hours of Work and the Manning of Ships http://www.admiraltylawguide.com/ conven/seafarershours1996.html

[5] IMO Resolution A.890(21);Annex II; Principles of Safe Manning 3.5.1. https:// mcanet.mcga.gov.uk/public/c4/regulations/safetyofnavigation/annex es/Annex06.htm

[6] Marine and Coastguard Agency. The Human element. A quide to Human behaviour in the shipping industry (2010), 120 pages http://www.nautinst.org/ filemanager/root/site_assets/forums/fatigue_forum/mca_the_human_ element_a_guide_to_human_behaviour_in_the_shipping_industry.pdf

[7] Maritime Labour Convention (2006). http://www.ilo.org/global/standards/ maritime-labour-convention/lang-en/index.htm

[8] SHE Manual (2011) Chapter 2, Section 6, Inspection Procedures https:// www.osha.gov/Firm_osha_data/100006.html

[9] Smith, A., Allen, P., Wadsworth, E. Seafarer Fatigue - Where next? (2006), 1-12 p. A summary document based on recent research from the Centre for Occupational and Health, Psychology, Cardiff University http://www.itfseafarers.org/ files/seealsodocs/3165/fatigue_where_next.pdf

[10] Smith, A. (2007). Adequate Crewing and Seafarers Fatigue: The International Perspective. Centre for Occupational and Health Psychology Cardiff University, 2007, 1-74 p. https://orcamwe.cf.ac.uk/48168/1/ITF\%20FATIGUE\%2OREPORT $\% 20 f$ inal.pdf

[11] STCW Manila amendments (2010)/ http://www.imo.org/en/OurWork/HumanEle ment/TrainingCertification/Pages/STCW-Convention.aspx

[12] Purinsš, A. (2015). Kuǵu navigācijas virsnieku darba slodzes izpēte un tās optimizācija/ "Assessment and optimization of workload of ship navigation officers": Magister Paper, Scientific adviser Dr. Helēna Šimkuva. Riga, Latvian Maritime academy,126 pages.

[13] Purinsš, A., Šimkuva, H. (2015). ASSESSMENT AND OPTIMIZATION OF WORKLOAD OF SHIP NAVIGATION OFFICERS: Research report on the 17th International Conference "Maritime Transport and Infrastructure", Riga, Latvian Maritime Academy Research Institute, 2015, 23-24 April. 